This Journal is available in Telkom University online Journals

Jurnal Manajemen Indonesia

\title{
Factors Causing the Poor Management of Village-Owned Enterprises (BUMDes) in Garut Regency
}

\author{
A.Ikeu Kania, \\ Universitas Garut, Faculty of Social and Political Sciences, Department of Public Administration
}

\begin{abstract}
The management of BUMDes in Garut Regency is still not in accordance with the mandate of the laws and regulations that its establishment is intended to create and to improve the prosperity of rural community life better through mobilization and management of village potential. This study aims to discover the factors that cause the low management of BUMDes in Garut Regency. Using a quantitative approach, the survey was conducted toward BUMDes management who are in the categories of semi-active and not yet active. A total of 161 respondents were selected by a simple random sampling method which was further analyzed using exploratory factor analysis with 32 indicators. The results showed that of the 32 indicators tested, 8 new factors are formed as factors that lead to poor management of BUMDes in Garut Regency. These factors include management, human resources, environmental conditions, personality, organization, policy, professionalism and communication.
\end{abstract}

Keywords-Management, Exploratory Factor Analysis, BUMDes, Rural Community

\begin{abstract}
Abstrak
Pengelolaan BUMDes di Kabupaten Garut masih belum sesuai dengan amanat peraturan perundang-undangan bahwa pembentukannya ditujukan untuk menciptakan dan meningkatkan kemakmuran kehidupan masyarakat desa yang lebih baik melalui mobilisasi dan pengelolaan potensi desa. Penelitian ini bertujuan untuk melihat faktor-faktor yang menyebabkan rendahnya pengelolaan BUMDes di Kabupaten Garut. Dengan menggunakan pendekatan kuantitatif, survey dilakukan pada pengurus BUMDes yang termasuk ke dalam katagori aktif namun kegiatannya belum sesuai dengan peraturan perundang-undangan dan BUMDes yang belum aktif. Sebanyak 161 responden dipilih dengan metode simpel random sampling yang selanjutnya dianalisis menggunakan exploratoryfaktor analysis dengan 32 indikator. Hasil penelitian menunjukkan bahwa dari 32 indikator yang diujikan, terbentuk 8 faktor yang menyebabkan rendahnya pengelolaan BUMDes di Kabupaten Garut. Faktor tersebut antara lain manajemen, sumber daya manusia, kondisi lingkungan, personality, organisasi, kebijakan, profesionalitas dan komunikasi.
\end{abstract}

Kata kunci-Pengelolaan, Exploratory Factor Analysis, BUMDes, Masyarakat Desa

\section{INTRODUCTION}

Law Number 6 of 2014 about Village gives the village a big opportunity of developing into the better one. The law states that village has an authority of managing its own household, including village economic management. Village economic problem should be solved comprehensively, from constructing infrastructure facilities, developing village economic potency, to optimizing such the potency and changing it into opportunity to support the villagers' economic productivity that in turn can improve villagers' welfare (Agunggunanto et al, 2016).

Village-Owned Enterprises, thereafter called BUMDes, is one of important part mandated in Village Law. BUMDes is born as a village institution functions to create villagers' wellbeing by utilizing its asset and potency

Article info

Received (11/09/2019)

Revised (28/04/2020)

Accepted (30/06/2020)

Corresponding_author: ikeukania@fisip.uniga.ac.id

DOI: $10.25124 /$ jmi.v20i2.3200

Copyright@2020. Published by School of Economics and Business - Telkom University 
and equipped with village's equity investment. The urgency of BUMDes is confirmed in (Permendesa or Minister of Village's Regulation Number 4 about BUMDes, 2015). The context of BUMDes establishment is expected to support economic village meaning that the establishment of BUMDes is oriented to institution's advantage, but more importantly the establishment of BUMDes should be able to provide both economic and social benefits to villagers.

The establishment and the development of BUMDes is the implementation of policy released by Ministry of Village, Disadvantage Area Development, Transmigration (PDTT) used not only to support physical development but also to expand productive economic business of rural people funded by village fund. BUMDes is one of village economic independence by activating strategic business units for village collective economic business through optimizing village asset and improving community business, and thereby can create market chance and network supporting the community need and increase villagers' income.

There are 74,910 Villages in Indonesia, 25\% of which have BUMDes, 75\% have not founded BUMDes, and out of 18,446 BUMDes founded only $20 \%$ have operated, the rest of $80 \%$ have name signboard only and have not operated yet (Bumdes, id, 2017). This condition is also true in Garut Regency, with 42 sub districts and 421 villages.

Only 150 BUMDes have belonged to active category. The characteristic of an active BUMDes is that it has operated corresponding to legislation through village asset and potency management activity and is not oriented to institution's profit only. Meanwhile, the rest of 204 BUMDes operate a variety of businesses more profit oriented and 67 BUMDes belong to inactive category. The profile indicates that BUMDes in Garut Regency has not been ideal yet. For more detailed information on the number of BUMDes in Garut Regency, see table 1 below.

Table 1. Number of BUMDes in Garut Regency 2019

\begin{tabular}{cccccc}
\hline Number of Sub District & $\begin{array}{c}\text { Number of } \\
\text { Village }\end{array}$ & $\begin{array}{c}\text { Number of } \\
\text { BUMDes }\end{array}$ & & \multicolumn{3}{c}{ Category } \\
\cline { 3 - 6 } & 421 & 421 & 150 & $\begin{array}{c}\text { Not Active } \\
\text { Yet }\end{array}$ & Inactive \\
\hline 42 & & & 204 & 67 \\
\hline
\end{tabular}

Source: DPMPD of Garut Regency 2019

BUMDes in Garut Regency has been established formally as a village government's institution or vehicle to implement economic empowerment program at village level. However, considering the result of observation and interview, the existence of BUMDes has not been able to stimulate and to activate the rural economic wheel. It is due to such problems as:

1. Low human resource capacity, so that village government and villagers' understanding on village potency mapping and identification cannot be explored yet to be the source of rural economic improvement;

2. Its establishment and management mechanism has not been compatible to legislation, so that many BUMDes are still merely profit-oriented;

3. BUMDes administrators' poor understanding on varying village equity investment and pattern and regulation in organizing economic activity;

4. Poor cooperative commitment development with third party, thereby not creating market chance and network yet to support the public service need;

5. Commitment established with third party still builds on mutual trust principle or without law certainty as law legality is still considered as unimportant.

Considering the background aforementioned, this research aims to find out the factors causing the poor management of Village-Owned Enterprise (BUMDes) in Garut Regency. The implication of research can be taken into account by Garut Regency government in making policy related to the design of BUMDes implementation acceleration program. 


\section{LITERATURE REVIEW}

Village-Owned Enterprise (BUMDes) is projected to arise as a new economic power in rural areas to manage village potency; therefore management is the key to rural economic development and a good management is required to activate the resources existing in an organization. BUMDes is a village business institution managed by villagers and village government in the attempt of reinforcing village economy and building social bonding within community based on village need and potency (Maryunani, 2008).

Minister of Interior's Regulation Number 39 of 2010 mentions BUMDes as a village business unit building on the spirits of independency, commonness, and mutual cooperation between village government and villagers. BUMDes is an institution established by village government and villagers for village's economic purpose as mandated in Permendesa (Minister of Village's Regulation) Number 4 of 2015, stating that BUMDes is a business unit belonging entirely or partially to village through direct participation deriving from village wealth (asset) separated to manage asset, service, and other business for the villagers' prosperity.

The establishment of BUMDes is intended as the attempt of accommodating all activities in economic and/or public service areas managed by village and/or in cooperation between villages intended not merely profit oriented, but also to contribute positively to rural development, particularly in economic and social areas, thereby reinforcing the rural economy in developing community economy, particularly in dealing with ASEAN Economic Community of 2015 (Alkadafi, 2015).

The objectives of BUMDes establishment as included in Permendesa No.4 of 2015 are: 1) to improve rural economy; 2) to optimize village asset in order to be beneficial to village prosperity; 3) to improve the community's business in managing rural economic potency; 4) to develop business cooperation plan between villages and/or between village and third party; 5) to create market chance and network supporting the public service need of citizens; 6) to provide job opportunity; 7) to improve the community's wellbeing through improving public service, rural economic growth, and even distribution; and 8) to increase the villagers' income and the Village Original Income.

Garut Regency, through policy as included in Local Regulation No.24 of 2011 about Guidelines of BUMDes Establishment and Management Mechanism, mentions that each of villages in Garut Regency should obligatorily have business unit, recalling the importance of BUMDES as the pillar of village economic growth. Therefore, an attempt to be taken to enable BUMDes to evolve and to achieve its objective is to manage it through the implementation of appropriate management functions.

Management function is the key to a successful management of an organization as suggested by Gullick (1965) introducing a well-known term in management process, POSDCORB. The 7 (seven) functions of management are: Planning; Organizing;Staffing; Directing; Coordinating; Reporting; Budgeting.

The implementation of functions should be conducted systematically from planning by selecting and setting the objective, organizing people by governing the mechanism through recruitment and building, and directing resource in order to cooperate to go to the same direction, and to write report corresponding to the planning and budgeting specified, to achieve the objective organization in order to provide something beneficial to the advance of organization, including BUMDES,

This research employed exploratory factor analysis to find out the factors causing the poor management of BUMDes in Garut Regency. The author conducted more in-depth exploration because BUMDes has its own uniqueness according to its area potency (Sudharma, 2016).

The importance of studying the factor causing business (SMEs and BUMDes) failure can provide new perspective to the organizer to make better business plan (Becker, Knyphausen-Aufseß, \& Brem, 2015). Business failure will provide freedom and motivation to keep trying anything not done before by the previous organizer (New York Magazine, n.d.)

A successful management of BUMDes is affected significantly by effective management from planning to supervision. A previous study emphasized more on the strategy of developing BUMDes (Sulaksana \& Nuryanti, 2019). Meanwhile, Ramadana (2013) studied the existence of BUMDes from rural economic reinforcement aspect that has not been able to support village income. Therefore, BUMDes as an economic institution at village level should be supported by village government in its implementation by conducting supervision and evaluation (Budiono, 2015). 
Considering the literature study on previous studies aforementioned, it can be seen different focuses of study. This research emphasizes on the management using management functions as the foundation of BUMDes management in Garut Regency. Management function concept is the key to an organization to achieve its objective successfully through the planned activities.

\section{RESEARCH METHODOLOGY}

This research employed quantitative approach, implemented in two stages. The first stage was interviewing a number of informants concerning the condition of BUMDes currently and the second stage is distributing questionnaire to the specified respondents. The first stage was conducted to acquire information becoming the factor tested later. About 32 (thirty two) factors were yielded from 6 (six) informants interviewed. Meanwhile the factors are presented in Table 2.

Table 2. Variable used in the research

\begin{tabular}{llll}
\hline No & Variable & No & Variable \\
\cline { 2 - 3 } 1 & Formal & 17 & Evaluation of Policy \\
2 & Informal & 18 & Creativity \\
3 & Social & 19 & Planning \\
4 & Voluntary & 20 & Communication Media \\
5 & Discipline & 21 & Organization \\
6 & Responsibility & 22 & Message \\
7 & Honesty & 23 & Staffing \\
8 & Socialization of Policy & 24 & Directing \\
9 & Standard policy & 25 & Coordinating \\
10 & Target of policy & 26 & Reporting \\
11 & Education & 27 & Budgeting \\
12 & Skill & 28 & Social Environment \\
13 & Expertise & 29 & Economic Environment \\
14 & Ability & 30 & Political Environment \\
15 & Innovativeness & 31 & Safety Environment \\
16 & Policy Implementation & 32 & Optimistic \\
& & & \\
\hline
\end{tabular}

In the second stage, the distribution of questionnaire is conducted by considering population, minimum sample, and sampling technique. The population of research consisted of BUMDes administrators belonging to active category but with activities incompatible to legislation and inactive BUMDes consisting of 271 BUMDes, To estimate the size of sample, Slovin's (Bungin, 2012) formula was used with error value of 5\%; therefore the minimum sample to be taken was 161 BUMDes in Garut Regency. The data collected was then analyzed using exploratory factor analysis with SPSS 22 software help. The profile of informants includes Chairperson of DPMPD and Head of BUMDes Division, Head of Villagers Economic Empowerment Section (3 persons) and Chairperson of Garut Regency's BUMDes Association and the number of sample BUMDes is presented in Table 3.

Table 3. Sample BUMDes

\begin{tabular}{cc}
\hline BUMDes Category & Total \\
\hline Not active yet (incompatible to Legislation) & 121 \\
\hline & 40 \\
\hline Inactive & 161 \\
\hline Total
\end{tabular}

Source: BPMPD of Garut Regency 2019 


\section{RESULT AND DISCUSSION}

The result of research shows the preliminary step taken to examine the analysis feasibility, to see the fulfilled assumption as the requirement of factor analysis implementation. Criteria used to find out whether or not a data can be analyzed using factor analysis are: Kaiser Meyer Olkin (KMO) coefficient and Bartlett's Sphericity test. Kaiser Meyer Olkin (KMO) test is necessary to see the adequacy of sample analyzed (sampling adequacy). This KMO score is found by comparing the observed correlation coefficient with the partial coefficient correlation.

The testing procedure is as follows:

1. KMO and Bartlett's test

The result of factor analysis shows KMO score and Bartlett's test as follows

Table 4. KMO And Bartlett's Test

\begin{tabular}{llr}
\hline Kaiser-Meyer-Olkin Measure of Sampling Adequacy. & .795 \\
\hline Bartlett's Test of Sphericity & Approx. Chi-Square & 2273.308 \\
\cline { 2 - 3 } & df & 465 \\
\cline { 2 - 3 } & Sig. & .000 \\
\hline
\end{tabular}

KMO and Bartlett's test score of 0.795 indicates that the score is higher than 0.5. Meanwhile, its significance value is 0.000 , or less than 0.05 ; therefore the variable is feasible to analyze further (Bartlett, 1965). The conclusion is confirmed with anti-image correlation score > (higher than) 0.5 .

2. Factoring and Rotation

\section{Communalities Analysis}

The next stage is to conduct factoring and rotation. Table 5 is communalities table. Communalities table is basically the number of variance or can be percentage of a variable. The higher the communalities score, the higher is the role of indicator in explaining the factor created (Santoso, 2015). Communalities table can be presented in the table below.

Table 5. Communalities

\begin{tabular}{lcr}
\hline & Initial & Extraction \\
\hline Formal Organization & 1.000 & .548 \\
Informal Organization & 1.000 & .719 \\
Social Organization & 1.000 & .664 \\
Voluntary Organization & 1.000 & .666 \\
Discipline & 1.000 & .748 \\
Responsibility & 1.000 & .751 \\
Honesty & 1.000 & .639 \\
Socialization of Policy & 1.000 & .636 \\
Standard Policy & 1.000 & .682 \\
Target of policy & 1.000 & .586 \\
Education & 1.000 & .686 \\
Skill & 1.000 & .671 \\
Expertise & 1.000 & .672 \\
Ability & 1.000 & .702 \\
Innovativeness & 1.000 & .623 \\
Policy Implementation & 1.000 & .737 \\
Evaluation of Policy & 1.000 & .689 \\
Creativity & 1.000 & .733 \\
Planning & 1.000 & .622 \\
Communication Media & 1.000 & .575 \\
Organization & 1.000 & .643 \\
Message & 1.000 & .574 \\
Staffing & 1.000 & .643 \\
& &
\end{tabular}




\begin{tabular}{lll} 
Directing & 1.000 & .632 \\
Coordinating & 1.000 & .673 \\
Reporting & 1.000 & .575 \\
Budgeting & 1.000 & .654 \\
Social Environment & 1.000 & .724 \\
Economic Environment & 1.000 & .618 \\
Political Environment & 1.000 & .733 \\
Safety Environment & 1.000 & .734 \\
\hline
\end{tabular}

The distribution of 32 (thirty two) variables can be seen in table 2. The figures (numbers) indicate the variance of variable that can be explained by the created factor. For example, formal organization variable has score of 0.548 , meaning that $54.8 \%$ of formal organization variable variance can be explained by the created factor. Furthermore, informal organization variable has score of 0.719 , meaning that $71.9 \%$ of informal organization variable variance can be explained by the created factors, and so do other variables.

\section{Total Variance Explained}

After the variables have been rotated, the next stage is to determine the factors created. To see how many new factors are created, see the table of total variance explained below.

Table 6. Total Variance Explained

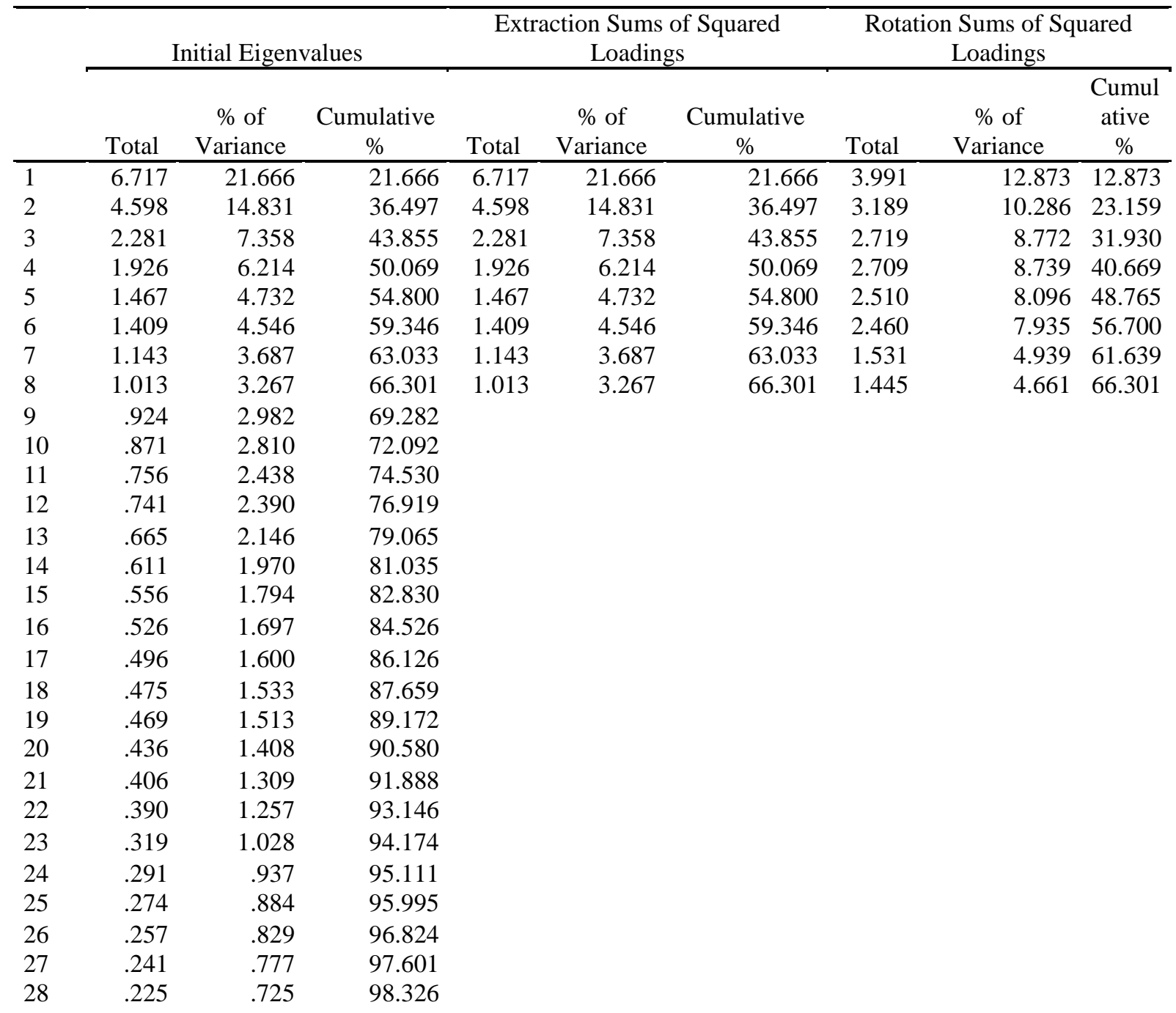




\begin{tabular}{rrrr}
29 & .207 & .667 & 98.993 \\
30 & .175 & .565 & 99.557 \\
31 & .137 & .443 & 100.000 \\
\hline
\end{tabular}

From the result of Total Variance Explained, it can be seen that eight factors are created, because its Eigenvalue $>1$. Considering the variables divided into eight optimum factors, each variable is then matched with appropriate factor.

\section{Loading Value}

Considering the result of factor analysis, the 32 factors are compressed into 8 factors created, in which the criteria of loading value is the variable with score of $>0.50$ only, while the lower one is ignored. The loading value of individual factors is as follows:

Table 7 Rotated Component Matrix

\begin{tabular}{|c|c|c|c|c|c|c|c|c|}
\hline & \multicolumn{8}{|c|}{ Component } \\
\hline & 1 & 2 & 3 & 4 & 5 & 6 & 7 & 8 \\
\hline Formal Organization & -.001 & .199 & -.097 & -.052 & .665 & .141 & .186 & .019 \\
\hline Informal Organization & .163 & .110 & .006 & .177 & .798 & -.021 & -.110 & .019 \\
\hline Social Organization & -.110 & .069 & .036 & .294 & .737 & -.006 & .127 & -.010 \\
\hline Voluntary Organization & -.022 & .078 & .093 & .514 & .613 & .085 & .020 & -.054 \\
\hline Discipline & .083 & .189 & .087 & .731 & .386 & .110 & .051 & -.012 \\
\hline Responsibility & .193 & .155 & -.021 & .781 & .200 & .182 & -.018 & .075 \\
\hline Honesty & -.068 & .279 & .054 & .702 & .052 & .236 & .042 & .012 \\
\hline Socialization of Policy & -.014 & .327 & .093 & .371 & .228 & .572 & -.058 & -.028 \\
\hline Standard Policy & .074 & .386 & -.116 & .301 & .143 & .614 & .108 & -.123 \\
\hline Target of Policy & -.029 & .413 & -.106 & .301 & .155 & .507 & -.174 & .028 \\
\hline Education & .074 & .787 & .062 & 199 & -.014 & .102 & .063 & -.045 \\
\hline Skill & .028 & .771 & .084 & .096 & .240 & .039 & .006 & -.005 \\
\hline Expertise & .034 & .766 & .132 & .021 & .191 & .160 & -.044 & .058 \\
\hline Ability & -.037 & .753 & .126 & .249 & .004 & .054 & .229 & .018 \\
\hline Innovativeness & .114 & .059 & .161 & .185 & .058 & .143 & .711 & -.130 \\
\hline Policy Implementation & .219 & .021 & -.009 & .158 & -.058 & .807 & .095 & .026 \\
\hline Evaluation of Policy & .116 & -.001 & .113 & -.025 & -.001 & .714 & .135 & .368 \\
\hline Creativity & .144 & .003 & .755 & .184 & -.003 & .006 & .328 & .017 \\
\hline Planning & .111 & .106 & -.092 & -.117 & .112 & .009 & .739 & .130 \\
\hline Communication media & .642 & -.253 & .079 & .169 & -.161 & .152 & .091 & .079 \\
\hline Organization & .472 & -.136 & .147 & -.159 & .051 & .206 & .246 & .499 \\
\hline Message & .549 & -.084 & .098 & -.167 & .104 & .178 & .108 & .417 \\
\hline Staffing & .335 & .074 & .103 & .134 & -.026 & .081 & -.094 & .693 \\
\hline Directing & .710 & .133 & .033 & .075 & .000 & .053 & .022 & .316 \\
\hline Coordinating & .795 & .056 & .033 & .008 & .082 & .122 & -.035 & .116 \\
\hline Reporting & .680 & .060 & .277 & .092 & .019 & -.008 & .114 & .100 \\
\hline Budgeting & .753 & .109 & .244 & .054 & -.053 & -.070 & .069 & -.022 \\
\hline Social Environment & .658 & .023 & .319 & -.129 & .157 & .102 & .026 & -.370 \\
\hline Economic Environment & .236 & .101 & .708 & .011 & .116 & .037 & -.135 & -.135 \\
\hline Political Environment & .197 & .142 & .778 & -.109 & .023 & .064 & -.165 & .159 \\
\hline Safety Environment & .192 & .129 & .774 & .075 & -.149 & -.080 & .131 & .171 \\
\hline
\end{tabular}

3. Interpretation of New Factor

Eight (8) new factors created from 32 variables can be seen in the table below. 
Table 8 New Factors

\begin{tabular}{|c|c|c|}
\hline No & Name of Loading Factors & Name of New Factors \\
\hline 1. & $\begin{array}{ll}\text { a. } & \text { Planning } \\
\text { b. } & \text { Organizing } \\
\text { c. } & \text { Staffing } \\
\text { d. } & \text { Directing } \\
\text { e. } & \text { Coordinating } \\
\text { f. } & \text { Reporting } \\
\text { g. } & \text { Budgeting }\end{array}$ & Management \\
\hline 2. & $\begin{array}{ll}\text { a. } & \text { Education } \\
\text { b. } & \text { Skill } \\
\text { c. } & \text { Expertise } \\
\text { d. } & \text { Ability }\end{array}$ & Human Resource \\
\hline 3. & $\begin{array}{ll}\text { a. } & \text { Social Environment } \\
\text { b. } & \text { Economic Environment } \\
\text { c. } & \text { Political Environment } \\
\text { d. } & \text { Safety environment }\end{array}$ & $\begin{array}{l}\text { Environment } \\
\text { Condition }\end{array}$ \\
\hline 4. & $\begin{array}{ll}\text { a. } & \text { Discipline } \\
\text { b. } & \text { Responsibility } \\
\text { c. } & \text { Honesty } \\
\end{array}$ & Personality \\
\hline 5. & $\begin{array}{ll}\text { a. } & \text { Formal Organization } \\
\text { b. } & \text { Informal Organization } \\
\text { c. } & \text { Social Organization } \\
\text { d. } & \text { Voluntary Organization }\end{array}$ & Organization \\
\hline 6. & $\begin{array}{ll}\text { a. } & \text { Socialization of Policy } \\
\text { b. } & \text { Standard Policy } \\
\text { c. } & \text { Target of Policy } \\
\text { d. } & \text { Policy Implementation } \\
\text { e. } & \text { Evaluation of Policy } \\
\end{array}$ & Policy \\
\hline 7. & $\begin{array}{ll}\text { a. } & \text { Innovativeness } \\
\text { b. } & \text { Creativity } \\
\end{array}$ & Professionalism \\
\hline 8. & $\begin{array}{ll}\text { a. } & \text { Communication Media } \\
\text { b. } & \text { Message }\end{array}$ & Communication \\
\hline
\end{tabular}

From the table above, it can be explained that after the factors have been created, the variables belonging to each of factors are in fact not as predicted. Therefore, a new representative label should be given to the variables belonging to each of factors. Factor 1 is labeled Management Factor because it contains the management from planning to budgeting, affecting the poor management of BUMDes in Garut Regency. Factor 2 is labeled Human Resource because the attributes within it contain the characteristics needed by human resource in managing BUMDes.

Then factor 3 is labeled Environment condition, because attributes within contain environmental condition from social, economic, politic, to safety environment. Factor 4 is labeled Personality factor because attributes within contains the ability to be owned by each individual in managing BUMDes. Factor 5 is labeled Organization factor because its attributes contain types of organization. Factor 6 is labeled Policy factor because its attributes contains the process of policy. Factor 7 is labeled Professionalism factor because its attributes contain the attitude to be owned by individuals. Factor 8 is labeled Communication because it contains information on communication media.

\section{CONCLUSION}

From the result of data analysis, the author can conclude that the thirty two variables studied can be reduced into eight new factors using factoring process. Then, the new factors created are: management factor consisting of planning, organizing, staffing, directing, coordinating, reporting, budgeting variables. Human resource factor consists of education, skill, expertise, and ability. Environment condition factor consists of social, economic, 
political, and safety environments. Personality factor consists of discipline, responsibility, and honesty. Organizational factor consists of formal, informal, social, and voluntary organizations. Policy factor consists of policy socialization, standard policy, policy target, policy implementation, and policy evaluation. Professionalism factor consists of innovativeness and creativity. Communication factor consists of communication media and message.

From the result of research, the management of BUMDes is recommended to improve human resource competency through education and training in order to map the rural economic potency. Further research is recommended to study the use of technology in BUMDes management.

\section{REFERENCES}

Agunggunanto, E. Y., Arianti, F., Kushartono, E. W., \& Darwanto. (2016). Pengembangan Desa Mandiri Melalui Pengelolaan Badan Usaha Milik Desa (BUMDes). Jurnal Dinamika Ekonomi dan Bisnis, 6781 .

Alkadafi, M. (2015). Penguatan Ekonomi Masyarakat Melalui Pengelolaan Kelembagaan Badan Usaha Milik Desa Menuju ASEAN Community. Jurnal ElRiyasah, 32-40.

Bartlett, M. (1950). Test of Significance in Factor Analysis. British Journal of Psychology, 77-85.

Becker, A., Knyphausen-Aufseß, D. Z., \& Brem, A. (2015). Beyond traditional developmental models: A fresh perspective on entrepreneurial new venture creation. International Journal of Entrepreneurial Venturing. https://doi.org/10.1504/IJEV.2015.068591

Budiono, P. (2015). Implementasi Kebijakan Badan Usaha Milik Desa (Bumdes) Di Bojonegoro (Studi di Desa Ngringinrejo Kecamatan Kalitidu Dan Desa Kedung primpen Kecamatan Kanor). Jurnal Politik Muda, 4(1), 116-125.

Chintary, V. Q., \& Lestari, A. W. (2016). Peran Pemerintah Desa Dalam Mengelola Badan Usaha Milik DEsa (BUMDes). Jurnal Ilmu Sosial dan Ilmu Politik UNITRI, 59-63.

Gulick, L. (1965). Educational Administration Edition. New York: Mc Graw Hill co.

Hasibuan. (2016). Manajemen Sumber Daya Manusia. Jakarta: PT Bumi Aksara.

Ichrom, Y. N., Suryono, A., \& Hanafi, I. (2017). Manajemen Tempat Pengelolaan Sampah Terpadu Berbasis Masyarakat (Suatu Studi Pada Dinas Cipta Karya dan Tata Ruang dan Tempat Pengelolaan Sampah Terpadu di Desa Mulyoagung Kabupaten Malang). Jurnal Administrasi Publik, 13(1), 35-41.

Kirowatil, D., \& Setia, L. D. (2018). Pengembagan Desa Mandiri Melalui BUMDes Dalam Meningkatkan Kesejahteraan Masyarakat Desa (Studi Kasus : Desa Temboro Kecamatan Karas Kabupaten Magetan. Jurnal AKSI, 15-22.

Maryunani. (2008). Pembangunan Bumdes dan Pemerdayaan Pemerintah Desa. Bandung: CV Pustaka Setia.

Murwadjia, T., Rahardjob, D.S., \& Hasna. (2017). BUMDES Sebagai badan hukum alternatif dalam pengembangan perkoperasian indonesia. Jurnal Hukum Kenotariatan dan ke-PPAT-an, 1-18.

NewYork Magzine. (n.d.). True tales of high-risk adoptions.

Ramadana, C. B. (2013). Keberadaan Badan Usaha Milik Desa (BUMDES) sebagai Penguatan Ekonomi Desa. Jurnal Administrasi Publik, 1(6), 1068-1076.

Samadi, Rahman, A \& Afrizal. (2015). Peranan Badan Usaha Milik Desa (BUMDes) dalam peningkatan ekonomi masyarakat (Studi Pada Bumdes Desa Pekan Tebih Kecamatan Hulu Kabupaten Rokan Hulu). Jurnal Mahasiswa Fakultas Ekonomi, 1-19.

Santoso, S. (2015). Menguasai Statistik Multivariat. Jakarta: PT Elex Media Kumputindo.

Setyobakti, H.M. (2017). Identification Of Business Enterprises Bumdes Based On Social And Economic Aspect (Case Study at BUMDes Ijen Lestari Tamansari Village District of Banyuwangi). Jurnal Ilmiah Bidang Akuntansi dan Manajemen (JEMA), 101-110.

Sudharma, K. J. A. (2016). Bumdes Suatu Teladan Untuk Mengembangkan Ekonomi Kreatif Desa. Jurnal Hukum, 3(2), 167-179.

Sulaksana J., \& Nuryanti, I. (2019). Strategi Pengembangan Badan Usaha Milik Desa (Bumdes) Kasus Di Bumdes Mitra Sejahtera Desa Cibunut Kecamatan Argapura Kabupaten Majalengka. Jurnal Ekonomi Pertanian dan Agribisnis (JEPA). 3(2), 348-359

Undang-undang Nomer 6 tahun 2014 tentang desa. Pasal 87 Mengenai Semangat yang melandasi pendirian dan pengelolaan BUMDes (Law Number 6 of 2014 about Village. Article 87 about Spirit Underlying the Establishment and the Management of BUMDes). 
Undang-undang Nomer 6 tahun 2014, Pasal 88 mengenai pendirian BUMDes (Law Number 6 of 2014, Article 88 about the Establishment of BUMDes).

Undang-undang Nomer 6 tahun 2014, Pasal 89 mengenai Manfaat berdirinya BUMDes (Law Number 6 of 2014, Article 89 about the Advantage of BUMDes Establishment) .

Undang-undang Nomer 6 tahun 2014, Pasal 90 mengenai arah pengembangan bisnis BUMDes yang bermanfaat bagi masyarakat desa (Law Number 6 of 2015, Article 90 about the Direction of BUMDes Business Development beneficial to Villagers).

Permendesa Nomer 4 tahun 2015 tentang BUMDes (Minister of Village's Regulation Number 4 of 2015 about BUMDes).

PP Nomor 43 Tahun 2014 yang diubah melalui PP Nomor 47 Tahun 2015 mengatur sumber daya dan arah pembangunan desa (Government Regulation Number 43 of 2014 amended with Government Regulation Number 47 of 2015 governing resource and direction of village development).

Peraturan Pemerintah (PP) no. 71 Tahun 2005 Tentang Desa (Government Regulation No.71 of 2005 about Village). 